\section{Effect of advertising spending on operating and market performance of banks: empirical evidence from Bangladesh}

Economic effect of advertising spending

\author{
Md. Ibrahim Molla \\ Department of Finance and Banking, University of Barishal, \\ Barishal, Bangladesh, and \\ Md. Kayes Bin Rahaman \\ School of Business, Bangladesh Open University, Gazipur, Bangladesh
}

Received 5 June 2021 Revised 13 July 2021 4 August 2021

23 August 2021

15 September 2021 Accepted 27 September 2021

\begin{abstract}
Purpose - The purpose of the paper is to empirically explore the economic effect of advertising spending on the performance of banks on a sample consisting of all banks listed on the Dhaka Stock Exchange over the period spanning from 2011 to 2019.

Design/methodology/approach - A dynamic panel data autoregressive approach of two-step system generalized method of moments (2-SGMM) estimation technique has been adopted in this study to analyze the contemporary and carryover effect of advertising on the financial performance of banks.

Findings - The findings indicate that advertising expenditure boosts banks' accounting returns but not their market value. Furthermore, advertising has a negative carryover effect on the financial performance of banks and is statistically significant for operating profit and return on equity. This finding demonstrates that the economic benefits of advertising expenditure lapse entirely within the current period and ought to be treated as an expense since it does not bring any future return for the banks in Bangladesh. In addition, this paper also offers no critical contrast between the impact of advertising spending on the performance of both conventional and Islamic banks operating in Bangladesh.

Originality/value - To the best of the authors' knowledge, no study so far has looked into the effect of advertising on the profitability and the market value of the banks operating in Bangladesh, and this is the first study that explores this relationship.
\end{abstract}

Keywords Advertising, Conventional banks, Islamic banks, System GMM, Bangladesh

Paper type Research paper

\section{Introduction}

Advertising, a marketing tool, is critical for communicating the product availability, features, benefits and establishing a company's brand (Peterson and Jeong, 2010). In addition, it is used to influence the attitudes and perceptions of the customers (Wies et al.,2019). Advertising also informs the customers about the new products and services and helps to stimulate the competition and demand in the market (Ali Shah and Akbar, 2008). According to Lou (2014), advertising works as a value relevant signal of future earnings, influencing the investors'

\section{JEL Classification - G21, M37}

(C) Md. Ibrahim Molla and Md. Kayes Bin Rahaman. Published in Asian Journal of Accounting Research. Published by Emerald Publishing Limited. This article is published under the Creative Commons Attribution (CC BY 4.0) licence. Anyone may reproduce, distribute, translate and create derivative works of this article (for both commercial and non-commercial purposes), subject to full attribution to the original publication and authors. The full terms of this licence may be seen at http:// creativecommons.org/licences/by/4.0/legalcode

Expressing acknowledgment to the anonymous reviewers and editors. There was no funding for this research.

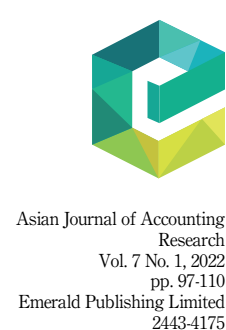

DOI 10.1108/AJAR-06-2021-0084 
AJAR 7,1

behavior (Joshi and Hanssens, 2010). Advertising spending promotes the goods and services of financial institutions, increases banks' cash flows and is considered an investment for wealth maximization (Chen, 2020).

Financial intermediaries such as commercial banks in Bangladesh, like other firms, spend a substantial amount of money on advertising their products and services to establish a brand and improve their profitability (Jensen and Jepsen, 2007). However, little empirical evidence exists about the financial performance of advertising spending for banks. Only a couple of studies (such as Chen, 2020; Mulchandani et al., 2019; Acar and Temiz, 2017; Mullineaux and Pyles, 2010) investigate the influence of advertising effectiveness on the banks' financial measures. Moreover, most of them are conducted in the developed economies and uses a variety of accounting measures. Therefore, a question is occupied in the minds of both the scholarly analysts and bank executives whether advertising spending has any impact on the financial outcomes of banks in Bangladesh.

The competition is fierce in the banking market in Bangladesh than a decade ago. A growing number of new bank approval, nonbank financial institutions, mutual funds and insurance companies have intensified this competition further. The nature of the development of new products of banks is not the same as other industries. Competitors in this sector can easily imitate any new product. Advertising can play a pivotal role in increasing awareness of banks' new products and services to gain a competitive advantage in the market. Therefore, it is imperative to look into the immediate and the long-term effects of advertising on a bank's outcome. Furthermore, no studies so far have investigated the role of advertising in the form of nonprice competition in relation to the banks operating in Bangladesh. This study has attempted to narrow the literature gap by exploring the effectiveness of advertising on the accounting performance and the market value of the banks recorded in the Dhaka Stock Exchange (DSE) using the data of nine years from 2011 to 2019. It has further investigated whether advertising spending affects the performance of the Islamic and conventional banks in the same direction or not.

The followings are some of the aspects in which this study expects to contribute to the current banks' nonprice competition literature. First, this research adds to the ongoing banking literature showing the effect of advertising on the performance of the banks in Bangladesh. The second contribution of this analysis is that in addition to accounting-based performances, we also find the influences of advertising expenditure on the market performance of the banks. Most of the prior works regarding advertising have been conducted within the context of created nations; a few studies have been conducted utilizing the data of Bangladeshi firms. In most cases, they have utilized the information of nonfinancial firms (such as Bhowmik et al., 2020). This paper focuses on the banking industry, intending to determine the impact of advertising intensity on the banks' performances in the context of an emerging market like Bangladesh. It also focuses on how the effect of the investment in advertising differs by the types of banks conventional versus Islamic banks. To the best of the authors' knowledge, no previous study so far has looked into the effect of advertising on the profitability and the market value of the banks operating in Bangladesh, and this is the first study that explores this relationship.

The aim of the research paper is not to derive any hypothesis; instead, we aim to address the following two research questions:

$R Q 1$. How does the investment in advertising affect the performance of banks listed in DSE?

$R Q 2$. Do the potential influences of advertising on banks' performance differ depending on the types of bank, such as conventional versus Islamic?

The residual part of the paper is structured as follows: Section 2 gives a quick summary of previous studies, followed by data and research methodology in Section 3. The 4th section 
presents the discussion of the estimated results. Finally, the last section discusses the summary and concludes with managerial implications, restrictions and future study directions.

\section{Literature review}

The literature on the nexus between advertising and firm performance uses different measures to proxy firm performance. Several earlier mainstream studies have tried to examine the influence of advertising on sales (Park and Jang, 2012), profit (Erickson and Jacobson, 1992; Acar and Temiz, 2017), firm value (Qi et al., 2018; Sridhar et al., 2016; Edeling and Fischer, 2016; Chauvin and Hirschey, 1993) and market share (Mullineaux and Pyles, 2010). However, the findings of prior empirical analyses are conflicting; some found that advertising is positively associated with the firm performance, while others found that it has an adverse or nonsignificant relation (Shah et al., 2019; Acar and Temiz, 2017; Meyer and Ujah, 2017; Tackx et al., 2017; Park and Jang, 2012; Denizci and Li, 2009; Lu and Beamish, 2004).

Advertising expenditures may be accumulated for a longer period to obtain future economic benefits that can affect the firm performance. Acar and Temiz (2017) investigate the long-term impact of advertisement on the financial performance of Turkish banks using Koyck's distributed lag models and report that advertising has a positive influence on bank performance. The authors argue that advertising provides future economic paybacks for the banks. They also suggest capitalizing and amortizing the advertising outlays to obtain future benefits for banks. Their finding is confirmed by Mulchandani et al. (2019) for Indian banks and claims that advertising expenditure has a long-term effect on banks' performance to some extent, and it can be capitalized for a few years. These results were opposed by Demsetz (1979), Ayanian (1983) and Erickson and Jacobson (1992). They suggested treating advertising as an expense and arguing that advertising does not provide any benefit beyond the current period. Shah and Akbar (2008) point out that, managers generally prefer to write off all expenditures in the current period due to the complexity of identifying the costs related to the projects and the magnitude of the future benefits. In a similar vein, applying the panel data, including an AR (1) disturbance for US banks, Mullineaux and Pyles (2010) confirm that the spending on advertising and promotion is positively associated with the bank profits and market shares. Riaz et al. (2015) come up with a similar result for Pakistani banks and claim that advertising expenditures increase the return on equity of Pakistani private commercial banks. Another recent study conducted by Chen (2020), employing the data of US bank holding companies, finds the same conclusion that increasing advertising spending enhances the banks' operating and financial performance.

Another approach is to investigate the influence of advertising spending on market value. To grasp the invisible nature of advertising, the direct value relation approach of market value is preferable to other approaches since it can capture the effect of advertising on current and future profitability (Shah and Akbar, 2008). Stock markets recognize marketing factors, and marketing decisions affect stock prices (Simon and Sullivan, 1993). The market value is determined by the combined earning power of both intangible and tangible assets. Advertising spending augments the market value of the firm (Qi et al., 2018). Sridhar et al. (2014) confirm that advertising outlays enhance the market value for high technology manufacturing firms in the United States. Shah et al. (2009) document a similar line of evidence that advertisement spending contributes positively to the market value of nonfinancial UK firms. Based on a multi-industry sample from the United States, Rahman et al. (2020a, b) argue that advertising productivity is positively associated with capital (a market-based performance indicator) that depends on market conditions.

\section{Economic effect of advertising spending}


AJAR

7,1

100

In contrast to the above findings, Connolly et al. (1986) find a negative influence of advertising expenditure on the market value. A similar view of thought is given by Bublitz and Ettredge (1989), who investigate the relationship of unexpected research and development (R\&D) and advertising spending with stock return and report that advertising expenditures are negatively connected to the stock return. The authors interpret advertising expenditures as expenses. However, Chan et al. (2001) find no direct relationship between advertisement spending and potential stock returns. Denizci and Li (2009) support their conclusion using the Compustat and American Consumer Satisfaction Index database data. They claim that advertising has no remarkable effect on the performance of tourism and hospitality industry.

From the above-discussed literature, it is clear that the previous research provides mixed findings. The mixed findings can be explained in the following ways. First, different researchers used the data from different countries, different industries and different time periods. Their data collection methods and estimations are not the same. Second, some authors use the static method to draw their inferences. The static methods have some limitations and produce biased and inefficient results if data belongs to the endogeneity problem. There is a common phenomenon of endogeneity issue in cause and effect measurements (Ullah et al., 2018). Most of the prior research overlooked the endogeneity issues in examining the cause and effect relationships, where the dependent variable is dynamic and might have a persistent nature.

The current study varies from previous studies in that it employs the dynamic panel data estimator to address the dynamic and other sources of endogeneity. Although there are many papers related to the influence of advertising expenditures on firms' performance, the literature on the impact of advertising on banks' financial position is scarce. This research has the potential to shed light on the advertising aspect of the banking sector. The banking institutions spend a considerable amount of money on advertising each year. However, there is little academic research on the effect of advertising on banks' profitability and market value. In addition, there is no such evidence with respect to the effectiveness of advertising spending on the operating and market performance of banks in Bangladesh. Earlier studies endeavor to measure the effectiveness of advertising on banks' performance, and most of them used the operating performance only and ignore the effect of advertising on the market value of banks. Therefore, this analysis uses both the operating and market performance of banks as a proxy for financial measures. Besides, there is no evidence on whether the effect of advertising differs by the types of banks conventional versus Islamic banks. The current study, therefore, attempts to fill this vacuity in the advertising and bank literature by analyzing the impact of investment in advertising on the accounting performance and market value of the banks. It will also identify whether any disparities in advertising power between traditional and Islamic banks in Bangladesh.

\section{Methodology}

\subsection{Data}

3.1.1 Outcome variables. This paper uses balanced panel data of all the listed banks in DSE over a nine-year period from 2011 to 2019 to explore the impact of advertisement spending on the performance of banks. We have used the BankFocus database and audited financial statements of banks to extract yearly financial data. Therefore, our research sample consists of 30 publicly listed banks in DSE. Following Rahman et al. (2020a, b), Kosmidou and Zopounidis (2008), Acar and Temiz (2017), Mullineaux and Pyles (2010) and Hirschey and Weygandt (1985), this study uses the log of operating profit (OP), return on assets (ROA) and return on equity (ROE) as the proxy of accounting-based financial performance, while 
Tobin's $Q$ has been utilized as a market-based performance indicator. Tobin's $Q$ is measured by the proportion of the market value of a bank to the asset's replacement costs. Both the accounting and market-based metrics have been employed in this analysis. The accounting ratios reflect the past performance of a bank, whereas Tobin's $Q$ reveals the stock market's expectations of the future performance of a bank.

3.1.2 Explanatory variables. The principal variable of interest in our analysis is the advertising expenditures of banks. The goal of the advertising expenditure is to "marry" a customer to a bank for building a relationship-specific investment (Mullineaux and Pyles, 2010). The variable $\ln A d v$ measures the annual advertising expenditures of the banks. To identify the carryover effect of advertising, we have used the one-year time lagged advertising expenditures. This analysis also uses some control variables based on precedence in the literature that can influence the banks' financial outcome, such as the liquidity ratio, size, non-performing loan ratio, interest rate and deposit rate of the banks. The $\log$ of total assets measures a bank's size. It is used to control the economies of scale (Bayer et al., 2020). The liquidity ratio is measured by dividing the current asset by total assets. Similarly, the ratio of nonperforming loans to total loans is used to measure the nonperforming loan ratio. Finally, we have calculated the proxy of the interest rate by dividing the interest income by total loans, and the deposit rate is found by the deposit expenses divided by the total deposit collection.

\subsection{Model specification}

Based on the variables as mentioned earlier, we have developed the following dynamic panel data generalized method of moments (GMM) model propounded by Arellano and Bond (1991) and Blundell and Bond (1998) to test the influence of advertising expenditure of banks on their financial performance.

$$
P_{i t}=\alpha_{0}+\lambda P_{i, t-1}+\sum_{i=1}^{n} \delta i(X i t)+\gamma n_{i t}+\mu_{i t}+\varepsilon_{i t}
$$

where $P_{i t}$ denotes the outcome of banks measured by OP, ROA, ROP and Tobin's Q. $P_{i, t-1}$ is a one-year lagged performance of banks. $X$ represents our primary independent variable measuring a bank's annual advertising expenditure (lnAdv). $\gamma n_{i t}$ shows the control variables in the model. $\mu_{i t}$ expresses firm-specific fixed effects, $\varepsilon_{i t}$ indicates the error term and $i$ and $t$ state the individual bank and time period, respectively. Following previous studies (for example, Qi et al., 2018; and Eng and Keh, 2007), we have included one-year time lag advertising expenditure in our models to observe the carryover effects of advertising on the performance of banks. In order to analyze the contemporaneous and carryover effect of advertising expenditure beyond the current period, our model (i) has been transformed into the following specific equations:

$$
\begin{aligned}
\mathrm{OP}_{i t}= & \alpha_{0}+\lambda_{1} * \mathrm{OP}_{i, t-1}+\delta_{2} * \ln \mathrm{ADV}_{i t}+\delta_{3} * \mathrm{ADV}_{i, t-1}+\gamma_{4} * \mathrm{LR}_{i t}+\gamma_{5} * \mathrm{SZ}_{i t} \\
& +\gamma_{6} * \mathrm{IR}_{i t}+\gamma_{7} * \mathrm{NPL}_{i t}+\gamma_{8} * \mathrm{DR}_{i t}+\varepsilon_{i t} \\
\mathrm{ROA}_{i t}= & \alpha_{0}+\lambda_{1} * \mathrm{ROA}_{i, t-1}+\delta_{2} * \ln \mathrm{ADV}_{i t}+\delta_{3} * \mathrm{ADV}_{i, t-1}+\gamma_{4} * \mathrm{LR}_{i t}+\gamma_{5} * \mathrm{SZ}_{i t} \\
& +\gamma_{6} * \mathrm{IR}_{i t}+\gamma_{7} * \mathrm{NPL}_{i t}+\gamma_{8} * \mathrm{DR}_{i t}+\varepsilon_{i t t} \\
\mathrm{ROE}_{i t}= & \alpha_{0}+\lambda_{1} * \mathrm{ROE}_{i, t-1}+\delta_{2} * \ln _{\mathrm{ADV}}+\delta_{3} * \mathrm{ADV}_{i, t-1}+\gamma_{4} * \mathrm{LR}_{i t}+\gamma_{5} * \mathrm{SZ}_{i t} \\
& +\gamma_{6} * \mathrm{IR}_{i t}+\gamma_{7} * \mathrm{NPL}_{i t}+\gamma_{8} * \mathrm{DR}_{i t}+\varepsilon_{i t}
\end{aligned}
$$

\section{Economic effect of advertising spending}


AJAR

7,1

$$
\begin{aligned}
\mathrm{TQ}_{i t}= & \alpha_{0}+\lambda_{1} * \mathrm{TQ}_{i, t-1}+\delta_{2} * \ln \mathrm{ADV}_{i t}+\delta_{3} * \mathrm{ADV}_{i, t-1}+\gamma_{4} * \mathrm{LR}_{i t}+\gamma_{5} * \mathrm{SZ}_{i t} \\
& +\gamma_{6} * \mathrm{IR}_{i t}+\gamma_{7} * \mathrm{NPL}_{i t}+\gamma_{8} * \mathrm{DR}_{i t}+\varepsilon_{i t}
\end{aligned}
$$

This study adopts the longitudinal data approach to determine the effect of advertising expenditure on banks' performance. The panel data is more informative and provides efficient results than time-series and cross-sectional data. However, it has some drawbacks, such as serial correlation and group-wise heteroskedasticity that must be considered to produce unbiased and reliable results (Hsiao, 2007). As a result, various diagnostic tests (such as unit root test, multicollinearity test, autocorrelation test, heteroskedasticity test and endogeneity test) have been performed to identify possible drawbacks in the dataset and to choose the best method to conduct the further analysis in order to confirm the robustness of our findings.

Im-Pesaran-Shin unit-root test has been applied for the unit root, and the result shows that the data are stationary from 1 to $5 \%$ level of significance. We have used the variance inflation factors (VIF) test to check the multicollinearity among explanatory variables. The results (given in Appendix) report that the value of VIF for each variable is less than 05, which tells us there is no multicollinearity among the variables. This study uses the Wooldridge test for autocorrelation, and it reports the presence of autocorrelation in the dataset used in this analysis. A Modified Wald test has been carried out to measure the group-wise heteroskedasticity. This test discovers group-wise heteroskedasticity presents in our dataset. Finally, we have applied the Durbin-Wu-Hausman (DWH) test for each independent variable of the models to find the possible endogeneity among the regressors. Our result suggests the presence of endogeneity in the variables of the models.

In summary, while the dataset is free from multicollinearity but it has a problem related to heteroscedasticity, autocorrelation and endogeneity. Endogeneity bias is a common problem in research settings examining cause and effect relationships, and ignoring it may lead to biased results (Ullah et al, 2018). An ordinary least square (OLS) regression technique will not provide a consistent and efficient result in the presence of above-mentioned problems, especially in the case of the endogeneity problem. As an alternative to OLS, the fixed or random effect method can address the unobserved heterogeneity issue, but it violates the strict exogeneity assumption. Besides, since the fixed effect estimator is a static model, it does not permit us to use the lag of dependent variables as a regressor to overcome the model's dynamic nature (Wooldridge, 2009).

This study, therefore, employs the dynamic panel data method of the two-step system GMM approach as a robust estimation to obtain consistent and unbiased estimates. In addition, this estimation deals with the dataset suffering from autocorrelation, heteroskedasticity and endogeneity. It controls the time-invariant unobserved heterogeneity, simultaneity and allows us to use the lag dependent variable to address the dynamic nature endogeneity in a dataset. This approach is intended for situations in which the dependent variable is dynamic and persistent, which can be affected by the previous values (Ullah et al., 2018). We have also applied the two-step robust command instead of one step because the two-step system GMM approach gives a robust standard covariance matrix in panel-specific autocorrelation and heteroskedasticity (Ullah et al, 2018; Rutz and Watson, 2019). Moreover, we have used the lag of endogenous variables as instruments in the models (Blundell and Bond, 1998; Arellano and Bover, 1995). Finally, there should be no second-order serial correlation among the residuals, and the instruments should be valid when judging dynamic panel data. At the end of the study, the Arellano-Bond AR (2) test is used to ensure that the residuals were free of second-order autocorrelation, and the Hansen J test is used to assess the validity of the instruments in the GMM model. Table 3 summarizes the findings of these analyses. 


\section{Empirical findings}

\subsection{Descriptive statistics}

The summary statistics of the explained and explanatory variables used in this analysis are summarized in Table 1. Among the accounting ratios, the average value of $\mathrm{OP}, \mathrm{ROA}$ and ROE is $10.36,0.79$ and 11.97 , respectively. The volatility of ROE is 4.97 , which is higher than other accounting ratios. The mean value of Tobin's $Q$ is 0.11 with a minimum of 0.01 and a maximum value of 2.05. This result implies that some banks are undervalued in this sample. The average level of advertising expenditure for sample banks is 17.81; with minimum advertising spending of 11.58 and a maximum of 20.93 .

\section{Economic effect of advertising spending}

103

\begin{tabular}{|c|c|c|c|c|c|}
\hline Variables & Mean & Std. Dev & Min & $\operatorname{Max}$ & \\
\hline OP & 10.36 & 0.68 & 7.86 & 11.93 & \\
\hline ROA & 0.79 & 1.49 & -13.92 & 3.65 & \\
\hline $\mathrm{ROE}$ & 11.97 & 4.97 & -10.33 & 28.28 & \\
\hline $\mathrm{TQ}$ & 0.11 & 0.17 & 0.01 & 2.05 & \\
\hline LnAdv & 17.81 & 1.30 & 11.58 & 20.93 & \\
\hline LR & 12.21 & 5.92 & 1.85 & 31.88 & \\
\hline $\mathrm{IR}$ & 0.11 & 0.03 & 0.035 & 0.18 & \\
\hline $\mathrm{DR}$ & 0.06 & 0.02 & 0 & 0.10 & \\
\hline NPL & 8.03 & 13.60 & 0 & 81.99 & Table 1. \\
\hline SZ & 14.398 & 0.856 & 11.271 & 16.298 & Summary statistics \\
\hline
\end{tabular}

\subsection{Correlation}

Table 2 illustrates the correlation between the independent variables employed in this study.

\begin{tabular}{|c|c|c|c|c|c|c|c|}
\hline Variables & LnAdv & LR & $\mathrm{IR}$ & $\mathrm{DR}$ & NPL & SZ & \\
\hline LnAdv & 1.000 & & & & & & \\
\hline LR & -0.112 & 1.000 & & & & & \\
\hline $\mathrm{IR}$ & 0.096 & 0.078 & 1.000 & & & & \\
\hline DR & 0.029 & -0.164 & 0.805 & 1.000 & & & \\
\hline NPL & -0.330 & 0.264 & -0.397 & -0.400 & 1.000 & & Table 2. \\
\hline $\mathrm{SZ}$ & 0.423 & -0.154 & -0.098 & -0.040 & -0.644 & 1.000 & Matrix of correlations \\
\hline
\end{tabular}

As can be observed from Table 2, advertising has a positive relationship with the bank's interest rate, deposit rate and size. However, it has a negative association with the liquidity and nonperforming loan ratio. The nonperforming loan has a negative relation with all the independent variables used in the study except the banks' liquidity. Similarly, the size of the banks has a negative association with LR, IR, DR and NPL, but it has a positive relationship with the advertising expenses of the banks. The correlation coefficients indicate that the coefficients are at an appropriate level for performing the regression, and there is no issue with multicollinearity in this study.

\subsection{Result and discussion}

The results of the two-step system GMM are illustrated in Table 3. Columns 1 to 3 report the result of model-I to model-III of accounting performance measurements of OP, ROA and ROE. The 4th column reports the results of model-IV for stock market performance measured by Tobin's $Q$. 


\begin{tabular}{|c|c|c|c|c|c|}
\hline \multirow{6}{*}{$\begin{array}{l}\text { AJAR } \\
7,1\end{array}$} & Variables name & Model-(I) OP & Model-(II) ROA & Model-(III) ROE & Model(IV) TQ \\
\hline & Dependent variable $_{(t-1)}$ & $0.310^{* * *}(0.119)$ & $0.603^{* * *}(0.046)$ & $0.388^{* * *}(0.164)$ & $0.231^{* * *}(0.092)$ \\
\hline & Advertising exp & $0.103^{*}(0.053)$ & $0.253^{* *}(0.117)$ & $1.289^{* * *}(0.598)$ & $0.001(0.011)$ \\
\hline & Advertising exp. $(t-1)$ & $-0.106^{* *}(0.043)$ & $-0.086(0.079)$ & $-1.269^{* *}(0.465)$ & $-0.013(0.010)$ \\
\hline & LR & $-0.045^{* *}(0.021)$ & $-0.011(0.012)$ & $-0.352^{*}(0.203)$ & $0.0001(0.002)$ \\
\hline & $\mathrm{SZ}$ & $1.144^{* * * *}(0.374)$ & $0.329(0.269)$ & $0.375(0.826)$ & $-0.053^{* *}(0.021)$ \\
\hline \multirow{9}{*}{104} & IR & $12.29^{* * *}(4.738)$ & 3.946 (4.828) & $127.2^{* *}(54.90)$ & $-0.215(0.672)$ \\
\hline & $\begin{array}{l}\mathrm{NPL} \\
\mathrm{DR}\end{array}$ & $-0.041^{* * *}(0.018)$ & $\begin{array}{r}0.003(0.003) \\
-3889(5.581)\end{array}$ & $\begin{array}{r}-0.037(0.072) \\
-1501^{* *}(5515)\end{array}$ & $\begin{array}{r}0.0003(0.002) \\
-0.925(0.661)\end{array}$ \\
\hline & $F$ statistic & $\begin{array}{c}-13.43 \quad(4.1325) \\
21492.7^{* * * *}\end{array}$ & $\begin{array}{l}-3.889 \text { (5.581) } \\
259.59 \text { ***** }\end{array}$ & $\begin{array}{l}-150.1 \\
224.15^{(5 . * 15 *}\end{array}$ & $\begin{array}{l}-0.925 \text { (0.661) } \\
71.81^{* * * *}\end{array}$ \\
\hline & Year effect & Yes & Yes & Yes & Yes \\
\hline & Groups/Instruments & $28 / 25$ & $29 / 22$ & $29 / 16$ & $29 / 27$ \\
\hline & $\mathrm{AR}(1)$ test ( $p$-value) & 0.006 & 0.007 & 0.029 & 0.176 \\
\hline & AR(2) test ( $(p$-value) & 0.205 & 0.123 & 0.107 & 0.665 \\
\hline & $\begin{array}{l}\text { Hansen test of over- } \\
\text { identification ( } \phi \text {-value) }\end{array}$ & 0.102 & 0.194 & 0.264 & 0.198 \\
\hline & cmd & xtabond2 & xtabond2 & xtabond2 & xtabond2 \\
\hline
\end{tabular}

Table 3.

Regression results of analysis using twostep system GMM
Note(s): This table depicts the dynamic panel data regression analysis using two-step system generalized method of moments (2SGMM). In the parentheses below the coefficients, the robust standard errors are shown. The symbols ${ }^{* * * * * *}$ and ${ }^{*}$ denote statistical significance at the 1,5 and $10 \%$ levels, respectively

Source(s): Authors own calculation

As shown in Table 3, the previous year's performance of banks in each model has a positive and significant effect on the current year's performance. These findings indicate that previous year profitability persists into the current year, which is in agreement with the existing research (such as Wintoki et al., 2012; Tuan and Tuan, 2016; and Anh and Anh, 2020; Rahman et al., 2020a, b) and suggest the analysis of advertising and bank performance should be conducted in a dynamic structure. We have used the one-year lag performance as an independent variable to capture the past effect on the present and to control the potential unobservable historical factors' effect on current year advertising expenditure and bank performance. This lag dependent variable acts as a proxy for an omitted variable bias in this sample (Wooldridge, 2009). Our result shows that advertising expenditure has a positive impact on the accounting performance of banks measured by OP, ROA and ROE. This result implies that advertising spending leads to higher profitability of the banks. This finding is in line with previous similar research for different countries (such as Chen, 2020; Acar and Temiz, 2017; Riaz et al., 2015; Mullineaux and Pyles, 2010; Ors, 2003), who claim that advertising is positively associated with banks' financial measures. However, our research finds no evidence of the significant impact of advertising on the market performance of banks measured by Tobin's $Q$. The insignificant relation between advertising outlays and market indicators implies that the majority of investors are indifferent about advertising spending because they feel it will not offer any benefit to the banks. The fact that advertising has different effects on accounting ratios and market indicators could be attributed to the nature of the performance metrics. Market value is a reflection of an investor's future expectations, including subjective judgment, and is influenced by emotions and irrational exuberance to some extent. On the other hand, accounting ratios reflect the firm's historical performance, and thus it does not carry the similar features inherent in Tobin's $Q$. Another possible justification may be that the nature of the capital market of Bangladesh with the inefficient market, small size, and high price volatility can not explain the behavior of advertising spending by banks.

The current study also finds that one-year lag advertising expenditure has a negative influence on the financial performance of banks, but it is statistically significant for operating profit and return on equity. This result confirms the previous studies of Han and Manry (2004), 
who conclude the advertising benefits are consumed in the current period. This finding suggests that advertising expenditure should be viewed as an immediate cost with occurrence like other expenses as the economic benefit of advertising expenditures expires fully in the current year for the banking sectors in Bangladesh. This finding sheds new light on the magnitude of advertising expenditure in the banking industry. Investment in advertising has a short-term impact on the accounting ratios, but it has no lagged effect on the market performance indicator of banks. The lack of carryover effect on the profitability and market value of banks indicates that the paybacks of advertising, like other expenses, expire in the current period and advertising expenditures should not be capitalized and amortized over time in order to receive the future benefits for the market value of the banks.

Of the control variables (although not the key focus of this study), the liquidity ratio negatively influences the operating profit and return on equity. However, they do not have any significant effect on the return on assets and the market value of banks operating in Bangladesh. Similarly, nonperforming loans are negatively associated with the operating profit of banks. These results insinuate that banks with higher levels of liquid assets and large amounts of nonperforming loans have a lower level of operating profit. It may be clarified by the fact that the higher the amounts of liquid assets, the lower the amounts of funds available to the banks for investment. The higher amount of nonperforming loans means the banks are unable to realize the loans and interest, which would erode the bank's profitability. Banks that offer higher deposit rates to attract the depositors have a lower level of profitability as the banks' cost to income is higher due to the high deposit rate. The interest rate is positively connected to the operating profit and $\mathrm{ROE}$ of the banks. These findings are in line with (Mullineaux and Pyles, 2010). It means the higher the interest rate, the higher the profitability of the banks. Size is positively linked to the banks' operating profit, but it is negatively allied with the market value of the banks (Bayer et al., 2020). This finding suggests that a bank's operating profit increases as it becomes large. However, the negative coefficient of size with the market value indicates the decreasing return to scale, and can be interpreted by the bureaucracy and procrastination of large banks (Chen, 2020).

4.3.1 Advertising effectiveness of conventional and Islamic banks. In addition, this study conducted the system GMM regression analysis for the traditional and Islamic banks separately to check whether the advertising expenditure influences both groups of banks' performance in the same direction or not. The detailed regression results for both Islamic banks and conventional banks are shown in Appendix (Tables II and III). A summary of empirical evidence results for conventional and Islamic banks for comparison purposes is given in Table 4. As reported in Table 4, it is found that the past year's performance has a

\begin{tabular}{|c|c|c|c|c|c|c|c|c|}
\hline \multirow{2}{*}{ Determinants } & \multicolumn{2}{|c|}{$\begin{array}{l}\text { Dependent } \\
\text { variable: } \mathrm{OP}\end{array}$} & \multicolumn{2}{|c|}{$\begin{array}{l}\text { Dependent } \\
\text { variable: ROA }\end{array}$} & \multicolumn{2}{|c|}{$\begin{array}{l}\text { Dependent variable: } \\
\text { ROE }\end{array}$} & \multicolumn{2}{|c|}{$\begin{array}{l}\text { Dependent variable: } \\
\text { TQ }\end{array}$} \\
\hline & $\begin{array}{l}\text { Conv. } \\
\text { Banks }\end{array}$ & Islam & $\begin{array}{l}\text { Conv. } \\
\text { Banks }\end{array}$ & $\begin{array}{l}\text { Islam } \\
\text { Banks }\end{array}$ & $\begin{array}{l}\text { Conv. } \\
\text { Banks }\end{array}$ & $\begin{array}{l}\text { Islam } \\
\text { banks }\end{array}$ & $\begin{array}{l}\text { Conv. } \\
\text { Banks }\end{array}$ & $\begin{array}{l}\text { Islam } \\
\text { banks }\end{array}$ \\
\hline $\begin{array}{l}\text { Dependent } \\
\operatorname{variable}_{(t-1)}\end{array}$ & $+* * *$ & $+* * *$ & $+* * *$ & $+* * *$ & $+* * *$ & $+* * *$ & $+* *$ & $+* *$ \\
\hline Advertising exp & $\varnothing$ & $\varnothing$ & $\varnothing$ & $+* * *$ & $\varnothing$ & $\varnothing$ & $\varnothing$ & $\varnothing$ \\
\hline Advertising $\exp _{(t-1)}$ & $\varnothing$ & $\varnothing$ & $\varnothing$ & $\varnothing$ & $\varnothing$ & $\varnothing$ & $\varnothing$ & $\varnothing$ \\
\hline
\end{tabular}

Note(s): This table demonstrates the summary of empirical evidence of the effect of advertising expenditure on the performance of Islamic banks and conventional banks. Symbols (+) and (Ø) indicate positive and no significant relationships, respectively. The asterisk signs of *** and** indicate statistical significance at the 1 and $5 \%$ levels, respectively

Source(s): Authors own calculation

\section{Economic effect of advertising spending}

105
Table 4.

Summary of empirical evidence results for conventional and Islamic banks: a comparison between conventional and Islamic banks 
AJAR 7,1

\section{6}

significant effect on the current year's performance for both the Islamic and conventional banks, indicating the persistent natures of bank performance. The current year advertising expenditure has no significant contemporaneous influence on most of the financial performance indicators of both groups of banks except for the return on assets of Islamic banks. We have found a positive relationship between advertising expenditure and return on assets for Islamic banks operating in Bangladesh. Our study also reports no significant relation between lagged one-year advertising expenditures and the profitability of both conventional and Islamic banks in Bangladesh. This finding suggests the benefit of advertising is expired in the same period for banks functioning in Bangladesh, and advertising is considered a direct expense like other expenses. Overall, there is no substantial difference between traditional and Islamic banks regarding the effects of advertisement spending on their performance, and the effect of advertising moves in the same direction for both. These findings are not consistent with Hamid et al. (2017), who claim that Islamic banks are doing better than conventional banks in breeding financial and non-financial performance for Malaysian banks.

Finally, from Table 3, we can see that the results of Hansen tests of over-identification suggest the instruments are valid, and AR(2) test statistics confirm the absence of serial correlation among the residuals in the models, which is a prerequisite for the dynamic model. The $F$ test statistics also confirm that all the models are significant.

\section{Summary and conclusion}

This research has empirically explored the economic effect of advertising spending on the performance of banks on a sample consisting of all banks listed on the DSE over a nine-year period from 2011 to 2019. We have adopted the dynamic panel data autoregressive approach of the 2-SGMM to examine the immediate and lagged effect of advertising on the accounting and the market performance of the banks. Our findings indicate that the previous year's performance has a positive and statistically significant influence on banks' accounting and market performance. This result indicates the persistent nature of the bank's performance and confirms that the analysis should be conducted in a dynamic framework. Furthermore, we find that advertising expenditure is positively associated with the financial measures of banks, and hence, it leads to the profitability of banks. However, our research finds no evidence of the impact of advertising on the market value of banks. Our study also reveals that one-year lag advertising expenditure has a negative effect on the financial performance of banks. However, it is statistically significant for $\mathrm{OP}$ and ROE. This result suggests that advertising expenditure should be treated as an expense as the economic benefit of advertising expenditures expires fully in the current year. Therefore, it does not bring any future return for the banks operating in Bangladesh. Finally, this paper also offers no substantial difference between the Islamic and conventional banks regarding the effects of advertisement spending on their performance, and the effect of advertising moves in the same direction for both.

The findings of the study have some noteworthy managerial implications. This study provides empirical evidence about the impact of advertising spending on the banks' performance. From the findings, the bank management would learn the strengths and weaknesses of their marketing strategies. It enables them to better coordinate and the uses of their resources. For instance, our result shows a positive association between advertising outlays and accounting performance, but it does not show any significant relationship between advertising and market performance. It indicates that banks' current marketing activities are effective for improving profitability. However, it does not improve stock market performance. Marketing executives of banks might focus more on customer relations than on investor relations. The results demonstrate that bank management should keep a close eye on developing an advertising strategy that is consistent with their customers and their 
investors. They should formulate an effective financial plan for advertising to build a longterm relationship with customers to provide potential economic gain and add market value to the banks.

With the previous research, this study has some insightful findings, but it also has some limitations that point to areas where further research is needed. Since we have used only the bank data within the accounting and financial context, the findings of the study may not be applicable to the other sectors which are operating in different market ecosystems. However, the strength of the results suggests that this is a fruitful line of study, opening the door for further investigation into other forms of firms and industries in different time periods. We did not recognize the form of advertising when analyzing the role of advertising in our research. Further research to determine the particular advertisement media that is effective for banks in attracting customers would be pretty interesting. The link between advertisement data, advertising strategies and financial institution performance could be another promising study area. Finally, in the case of other sectors or countries, the findings of this analysis should be viewed with caution.

\section{References}

Acar, M. and Temiz, H. (2017), "Advertising effectiveness on financial performance of banking sector: turkey case”, International Journal of Bank Marketing, Vol. 35 No. 4, pp. 649-661, doi: 10.1108/ IJBM-03-2016-0036.

Ali Shah, S.Z. and Akbar, S. (2008), "Value relevance of advertising expenditure: a review of the literature”, International Journal of Management Reviews, Vol. 10 No. 4, pp. 301-325, doi: 10. 1111/j.1468-2370.2007.00228.x.

Anh, P.D. and Anh, H.T.P. (2020), "Does corporate governance structure matter for firm financial performance? A system GMM panel analysis for Vietnam", Journal of International Economics, Vol. 20 No. 1, pp. 1-17, doi: 10.38203/jiem.020.1.0001.

Arellano, M. and Bond, S. (1991), "Some tests of specification for panel data: monte Carlo evidence and an application to employment equations", Review of Economic Studies, Vol. 58 No. 2, pp. 277-297, doi: 10.2307/2297968.

Arellano, M. and Bover, O. (1995), "Another look at the instrumental variable estimation of errorcomponents models", Journal of Econometrics, Vol. 68 No. 1, pp. 29-51, doi: 10.1016/03044076(94)01642-D.

Ayanian, R. (1983), "The advertising capital controversy”, Journal of Business, Vol. 56, pp. 349-363, available at: http://www.jstor.org/stable/2352802.

Bayer, E., Srinivasan, S., Riedl, E.J. and Skiera, B. (2020), "The impact of online display advertising and paid search advertising relative to offline advertising on firm performance and firm value", International Journal of Research in Marketing, Vol. 37, pp. 789-804. doi: 10.1016/j.ijresmar.2020. 02.002.

Bhowmik, A.R., Hossain, M.K., Vangpadith, V. and Chowdury, N. (2020), "Analyzing the impact of advertising and sales promotion costs on sales revenues and profits of DSE listed ceramic companies in Bangladesh”, Global Journal of Management and Business Research (D), Vol. XX No. II, Version 1, pp. 11-17.

Blundell, R. and Bond, S. (1998), "Initial conditions and moment restrictions in dynamic panel data models", Journal of Econometrics, Vol. 87 No. 1, pp. 115-143.

Bublitz, B. and Ettredge, M. (1989), "The information in discretionary outlays: advertising, research and development", The Accounting Review, Vol. 64, pp. 108-124, available at: http://www.jstor. org/stable/248131.

Chan, L.K.C., Lakonishok, J. and Sougiannis, T. (2001), "The stock market valuation of research and development expenditures", Journal of Finance, Vol. 56 No. 6, pp. 2431-2456, doi: 10.1111/00221082.00411.

\section{Economic effect of advertising spending}


AJAR

7,1

108

Chauvin, K.W. and Hirschey, M. (1993), "Advertising, R\&D expenditures and the market value of the firm”, Journal of Financial Management, Vol. 22 No. 4, pp. 128-140, available at: https:// econpapers.repec.org/RePEc:fma:fmanag:chauvin93.

Chen, K. (2020), "The effects of marketing on commercial banks' operating businesses and profitability: evidence from US bank holding companies", International Journal of Bank Marketing, Vol. 38 No. 5, pp. 1059-1079, doi: 10.1108/IJBM-08-2019-0301.

Connolly, R.A., Hirsch, B.T. and Hirschey, M. (1986), "Union rent seeking, intangible Capital, and market value of the Firm", Review of Economics and Statistics, Vol. 68 No. 4, pp. 567-577.

Demsetz, H. (1979), "Accounting for advertising as a barrier to entry”, Journal of Business, Vol. 52, pp. 345-360, available at: https://www.jstor.org/stable/2352366.

Denizci, B. and Li, X.R. (2009), "Linking marketing efforts to financial outcome: an exploratory study in tourism and hospitality contexts", Journal of Hospitality and Tourism Research, Vol. 33 No. 2, pp. 211-226, doi: 10.1177/1096348008329871.

Edeling, A. and Fischer, M. (2016), "Marketing's impact on firm value: generalizations from a metaanalysis", Journal of Marketing Research, Vol. 53 No. 4, pp. 515-534, available at: http://hdl. handle.net/10453/122015.

Eng, L.L. and Keh, H.T. (2007), "The effects of advertising and brand value on future operating and market performance", Journal of Advertising, Vol. 36 No. 4, pp. 91-100, doi: 10.2753/JOA00913367360407.

Erickson, G. and Jacobson, R. (1992), "Gaining comparative advantage through discretionary expenditures: the returns to R\&D and advertising”, Management Science, Vol. 38 No. 9, pp. 1264-1279, available at: https://www.jstor.org/stable/2632633.

Hamid, B.A., Najibullah, S. and Habibullah, M.S. (2017), "Marketing effectiveness of islamic and conventional banks: evidence from Malaysia”, in Alam, N. and Rizvi, S.A.R. (Eds), Islamic Banking, Palgrave CIBFR Studies in Islamic Finance, pp. 51-80, doi: 10.1007/978-3-319-45910-3_4.

Han, B.H. and Manry, D. (2004), "The value-relevance of R\&D and advertising expenditures: evidence from Korea", The International Journal of Accounting, Vol. 39, pp. 155-173, doi: 10.1016/j.intacc. 2004.02.002.

Hirschey, M. and Weygandt, J.J. (1985), "Amortization policy for advertising and research and development expenditures", Journal of Accounting Research, Vol. 23 No. 1, pp. 326-335.

Hsiao, C. (2007), "Panel data analysis-advantages and challenges", Test, Vol. 16 No. 1, pp. 1-22, doi: 10. 1007/s11749-007-0046-x.

Jensen, B.M. and Jepsen, L.A. (2007), "Low attention advertising processing in B2B markets", Journal of Business and Industrial Marketing, Vol. 22 No. 5, pp. 342-348.

Joshi, A. and Hanssens, D.M. (2010), "The direct and indirect effects of advertising spending on firm value", Journal of Marketing, Vol. 74 No. 1, pp. 20-33, doi: 10.1509/jmkg.74.1.20.

Kosmidou, K. and Zopounidis, C. (2008), "Measurement of bank performance in Greece", SouthEastern Europe Journal of Economics, Vol. 1 No. 1, pp. 79-95.

Lou, D. (2014), "Attracting investor attention through advertising”, The Re-view of Financial Studies, Vol. 27 No. 6, pp. 1797-1829, available at: https://www.jstor.org/stable/24465651.

Lu, J.W. and Beamish, P.W. (2004), "International diversification and firm performance: the S-curve hypothesis", Academy of Management Journal, Vol. 47, pp. 598-609, available at: http://www. jstor.org/stable/20159604.

Meyer, H.M. and Ujah, N.U. (2017), "Managed earnings: the negative impact of marketer's discretionary advertising expenditures on firm performance", Marketing Intelligence and Planning, Vol. 35, pp. 192-204, doi: 10.1108/MIP-03-2016-0045.

Mulchandani, K., Mulchandani, K. and Attri, R. (2019), "An assessment of advertising effectiveness of Indian banks using Koyck model", Journal of Advances in Management Research, Vol. 16 No. 4, pp. 498-512, doi: 10.1108/JAMR-08-2018-0075. 
Mullineaux, D.J. and Pyles, M.K. (2010), "Bank marketing investments and bank performance", Journal of Financial Economic Policy, Vol. 2 No. 4, pp. 326-345, doi: 10.1108/17576381011100856.

Ors, E. (2003), "The role of advertising in commercial banking", Proceedings 850, Federal Reserve Bank of Chicago, available at: https://www.academia.edu/35435277.

Park, K. and Jang, S. (2012), "Duration of advertising effect: considering franchising in the restaurant industry", International Journal of Hospitality Management, Vol. 31 No. 1, pp. 257-265, doi: 10. 1016/j.ijhm.2011.05.001.

Peterson, R.A. and Jeong, J. (2010), "Exploring the impact of advertising and R\&D expenditures on corporate brand value and firm-level financial performance", Journal of the Academy of Marketing Science, Vol. 38, pp. 677-690, doi: 10.1007/s11747-010-0188-3.

Qi, R., Cárdenas, D.A., Mou, X. and Hudson, S. (2018), “The strategic value of advertising expenditures in the tourism and hospitality industry", Tourism Economics, Vol. 24 No. 7, pp. 872-888, doi: 10. 1177/1354816618786845.

Rahman, M., Rodríguez-Serrano, M.Á. and Hughes, M. (2020a), "Does advertising productivity affect organizational performance? Impact of market conditions", British Journal of Management, Vol. 00, pp. 1-25, doi: 10.1111/1467-8551.12432.

Rahman, M., Rodríguez-Serrano, M.Á. and Lambkin, M. (2020b), "Advertising efficiency and profitability: evidence from the pharmaceutical industry", Industrial Marketing Management, Vol. 89, pp. 619-629, doi: 10.1016/j.indmarman.2019.02.001.

Riaz, S., Furqan, M. and Siddique, S.S. (2015), "Advertising influence on the profitability of public and private sector commercial banks", Journal of Business Economics, Vol. 7 No. 191, pp. 1-5, doi: 10. 4172/2151-6219.1000191.

Rutz, O.J. and Watson, G.F. (2019), "Endogeneity and marketing strategy research: an overview", Journal of the Academy of Marketing Science, Vol. 47, pp. 479-498, doi: 10.1007/s11747-01900630-4.

Shah, S.Z.A. and Akbar, S. (2008), "Value relevance of advertising expenditure: a review of the literature”, International Journal of Management Reviews, Vol. 10 No. 4, pp. 301-325, doi: 10. 1111/j.1468-2370.2007.00228.x.

Shah, S.Z.A., Stark, A.W. and Akbar, S. (2009), "The value relevance of major media advertising expenditures: some UK evidence", The International Journal of Accounting, Vol. 44 No. 2, pp. 187-206, doi: 10.1016/j.intacc.2009.03.004.

Shah, S.Z.A., Akbar, S., Stark, A.W. and Ahmad, S. (2019), "Advertising, earnings prediction and market value: an analysis of persistent UK advertisers", British Journal of Management, Vol. 00, pp. 1-23, doi: 10.1111/1467-8551.12378.

Simon, C.J. and Sullivan, M.W. (1993), "The measurement and determinants of brand equity - a financial approach”, Marketing Science, Vol. 12 No. 1, pp. 28-52, doi: 10.1287/mksc.12.1.28.

Sridhar, S., Narayanan, S. and Srinivasan, R. (2014), "Dynamic relationships among R\&D, advertising, inventory and firm performance", Journal of the Academy of Marketing Science, Vol. 42, pp. 277-290, doi: 10.1007/s11747-013-0359-0.

Sridhar, S., Germann, F., Kang, C. and Grewal, R. (2016), "Relating online, regional, and National Advertising to firm value", Journal of Marketing, Vol. 80 No. 4, pp. 39-55, doi: 10.1509/jm. 14.0231 .

Tackx, K., Rothenberger, S. and Verdin, P. (2017), "Is advertising for losers? An empirical study from a value creation and value capturing perspective", European Management Journal, Vol. 35, pp. 327-335.

Tuan, N.V. and Tuan, N.A. (2016), "Corporate governance structures and performance of firms in asian markets: a comparative analysis between Singapore and Vietnam", Organizations and Markets in Emerging Economies, Vol. 7, No. 2(14), pp. 112-140.

Ullah, S., Akhtar, P. and Zaefarian, G. (2018), "Dealing with endogeneity bias: the generalized method of moments (GMM) for panel data”, Industrial Marketing Management, Vol. 71, pp. 69-78.

\section{Economic effect of advertising spending}


AJAR

7,1

110

Wies, S., Hoffmann, A.O., Aspara, I.J. and Pennings, J.M. (2019), “Can advertising investments counter the negative impact of shareholder complaints on firm value?”, Journal of Marketing, Vol. 83 No. 4, pp. 58-80, doi: 10.1177/0022242919841584.

Wintoki, M.B., Linck, J.S. and Netter, J.M. (2012), "Endogeneity and the dynamics of internal corporate governance", Journal of Financial Economics, Vol. 105 No. 3, pp. 581-606, doi: 10.1016/j.jfineco. 2012.03.005.

Wooldridge, J.M. (2009), Introductory Econometrics: A Modern Approach, 4th ed., South-Western Cengage Learning, Mason.

\section{Appendix}

Appendix is available online at: https://docs.google.com/document/d/1wDHMDOVKdOnYub7p-_ PJz312AUw6qrKH/edit?usp = sharing\&ouid =101681229394156350766\&rtpof $=$ true\&sd $=$ true

\section{Corresponding author}

Md. Ibrahim Molla can be contacted at: mmibrahimfnb@gmail.com

For instructions on how to order reprints of this article, please visit our website: www.emeraldgrouppublishing.com/licensing/reprints.htm Or contact us for further details: permissions@emeraldinsight.com 